\title{
Helicobacter pylori and non-steroidal anti-inflammatory drugs: uncomfortable partners in peptic ulcer disease
}

Recent studies have suggested that Helicobacter pylori and non-steroidal anti-inflammatory drugs (NSAIDs) are capable of interfering with various protective mechanisms in the gastroduodenal mucosa. Whereas NSAIDs are recognised for their acid stimulating activity, the effect of $H$ pylori on gastric acid secretion remains highly speculative despite its association with hypergastrinaemia. Both $H$ pylori and NSAIDs have, however, been shown to influence the production rate and the quality of gastric cyclic AMP, the mucus layer, mucosal prostaglandins, blood flow, and platelet activating factor. Characteristic histological abnormalities have also been identified. Also NSAID related peptic ulcers seem to develop more commonly in patients infected with $H$ pylori despite the apparent reduction in the prevalence of these organisms in chronic NSAID users, hence the uncomfortable relation between the two aetiological factors. It remains to be seen whether the eradication of $H$ pylori would reduce the frequency of peptic ulcers induced by NSAIDs or prevent their recurrence.

Helicobacter pylori and NSAIDs are probably the commonest known exogenous factors in the aetiology of peptic ulcer disease. This paper describes the pathogenetic mechanisms common to $H$ pylori and NSAIDs and discusses the possibility of a synergistic relation between them. The importance of such a relation, if present, relates to its potential to provide a new therapeutic approach to the common, but yet unresolved, problem of ulcers induced by NSAIDs.

\section{Effect of NSAIDs and $H$ pylori on gastric acid secretion}

Because of the widely accepted importance of gastric acid in the pathogenesis of ulcers in general, it was only natural for many workers to investigate the possible effects of NSAIDs and, more recently, $H$ pylori on acid secretion. NSAIDs (indomethacin and aspirin in particular) were found to increase basal and maximally stimulated gastric acid secretion ${ }^{13}$; they seem to bypass the $\mathrm{H}_{2}$ and muscarinic receptors and interact with secretagogues at a locus between the catalytic subunit of adenylate cyclase activation and the proton pump. ${ }^{4}$ The potentiation of secretagogue stimulated acid secretion by non-salicylate NSAIDs has also been found to be dependent on calcium. ${ }^{4}$

The situation is not so well defined in the case of $H$ pylori. Because of its association with hypergastrinaemia, it was speculated that $H$ pylori could increase the parietal cell mass that is characteristic of patients with duodenal ulcers. ${ }^{5}$ To date, the evidence for an increase in gastric acid secretion by $H$ pylori has, however, been lacking. ${ }^{56}$ On the contrary, there is a consensus that acute exposure to $H$ pylori causes hypochlorhydria. ${ }^{7-11}$

Recent evidence indicates that hypergastrinaemia associated with $H$ pylori might not be directly related to the function of the parietal cells, ${ }^{12}$ the number of antral G cells, ${ }^{13}$ or to the bacterium's urease activity. ${ }^{14}$ It is more likely to be related to local inflammation ${ }^{13-15}$ or products of the $T$ lymphocyte such as interleukin-2 and $\gamma$-interferon. ${ }^{16}$ Gastric acid secretion in chronic NSAID users who are infected with $H$ pylori has not been studied, but indomethacin has been shown to potentiate the inhibitory effect of $H$ pylori protein on gastric fundic cyclic AMP, which in turn mediates acid secretion in vitro. ${ }^{17}$ This might explain, at least in part, the tendency of many arthritic patients to develop a degree of hypochlorhydria, ${ }^{18}$ and the limitations of acid inhibition in the management of NSAID related ulcers. ${ }^{1920}$

\section{The mucus layer}

The ability to change the characteristics of the gastric mucus layer is common to both NSAIDs and $H$ pylori. Aspirin ${ }^{21}$ and indomethacin ${ }^{22}$ were found to inhibit mucus secretion. Aspirin can also increase pepsin mediated proteolysis of mucus, decrease mucus viscosity, and increase the permeability of mucus to hydrogen ion..$^{23}$ Indomethacin was shown to inhibit active bicarbonate secretion by the gastric mucosa. ${ }^{24}$ It was also suggested that NSAIDs could cause disruption of the gastric mucosal barrier, which in turn allows back diffusion of hydrogen ion with its damaging results. ${ }^{25-27}$

Similarly, it has recently been shown that incubation of a culture filtrate of $H$ pylori with gastric mucus could lead to a gradual loss of viscosity of mucus, ${ }^{28}$ which might impair the ability of the mucus to retard the diffusion of hydrogen ions. It was concluded that the degenerative changes produced in the gastric mucus gel by $H$ pylori might be a contributing factor to the pathogenesis of gastritis and peptic ulcers. ${ }^{28}$

\section{Mucosal prostaglandins}

It is generally accepted that NSAIDs, with few exceptions, ${ }^{29}$ are capable of suppressing gastric and duodenal mucosal prostaglandin (PG) synthesis, although no correlation has been found between the degree of inhibition of PG and the endoscopic abnormalities. ${ }^{29} 30$

Because of its strong association with gastritis and neutrophilic infiltration, $H$ pylori is expected, at least in theory, to stimulate PG production, as human neutrophils and macrophages are capable of synthesising PGs. ${ }^{31}$ Also gastritis - like any other inflammation - is associated with raised PG values irrespective of $H$ pylori status. ${ }^{32}{ }^{33}$ It was surprising, therefore, to find that patients with $H$ pylori related gastritis had PG values similar to those without $H$ pylori. ${ }^{33-35}$ This led to speculation that $H$ pylori infection might result in at least a partial block in PG synthesis at the level of the neutrophils, mucosal cells, or both. ${ }^{33}$ Indeed, some workers reported reduced concentrations of stable metabolites of $\mathrm{PGI}_{2}$ in patients infected with $H$ pylori, ${ }^{36}$ but this was not confirmed by others. ${ }^{33-35}$ It was also interesting to find that, in vitro, the combination of indomethacin and $H$ pylori culture filtrate reduced gastric antral mucosal $\mathrm{PGE}_{2}$ and epithelial viability to a greater degree than indomethacin alone. ${ }^{37}$ This in turn might suggest a synergistic relation between $H$ pylori and NSAIDs in causing mucosal damage. 


\section{Mucosal blood flow}

Several studies have shown that short courses of NSAIDs could reduce gastric mucosal blood flow in laboratory animals. ${ }^{283}$ The situation is not clear in patients on long term NSAIDs, who could have other factors that might alter blood flow. Also, little is known about the duodenal microcirculation in such patients. It has been shown, however, that duodenal, but not gastric, mucosal blood flow is lowest in NSAID patients who smoke, or those with duodenal ulcers or $H$ pylori $^{40}$; no correlation could be found with age or sex. Further analysis of the data in this study ${ }^{40}$ showed that the suppressive effect of smoking and $H$ pylori on duodenal blood flow in NSAID patients was independent of ulceration and other demographic variables. Although such findings do not dispute the capacity of NSAIDs to lower mucosal blood flow in general, they might represent another aspect of the synergistic relation thought to exist between NSAIDs and $H$ pylori, at least for duodenal blood flow.

\section{Histological and endoscopic abnormalities}

Active chronic gastritis is the classic histological picture found in association with $H$ pylori in most infected subjects. It is best remembered as the main abnormality seen after the deliberate ingestion of the organisms to fulfil Koch's postulates for the pathogenicity of $H$ pylori, ${ }^{78}$ and in epidemic gastritis. ${ }^{9}$ It is also the commonest histological finding in patients treated with NSAIDs. ${ }^{41}$ Neutrophilic infiltration, common to most cases of NSAID and $H$ pylori gastritis, could be related to the capacity of NSAIDs and $H$ pylori to stimulate the production of platelet activating factor. ${ }^{42}{ }^{43}$ As well as its ulcerogenic actions, ${ }^{42}$ platelet activating factor might be involved in the aggregation and activation of neutrophils, ${ }^{44}$ which might subsequently contribute to ulcer formation: neutropenic rats are less likely to develop gastric mucosal injury from indomethacin or naproxen. ${ }^{44}$ These interesting findings might not apply, however, to patients with chemical gastritis, another histological abnormality characteristic of chronic NSAID intake. ${ }^{414}$ Not unlike bile reflux gastritis in patients with a history of gastroduodenal surgery, ${ }^{47}$ it is characterised by foveolar hyperplasia, vasodilatation, oedema, lack of inflammatory cells, and the presence of muscle fibres in the lamina propria..$^{41}{ }^{46-49} \mathrm{H}$ pylori is very rare in cases of chemical gastritis, ${ }^{41} \% 47$ and the histological picture can be found in about $25 \%$ of chronic NSAID users. ${ }^{416}$ The importance of such an entity stems from the positive correlation between the histological chemical scores and the degree of endoscopic damage: peptic ulcers related to NSAIDs and measuring $5 \mathrm{~mm}$ in diameter were found more commonly in patients with chemical gastritis or gastritis associated with $H$ pylori than in those without either of these conditions. ${ }^{41}$ This is in agreement with other studies, ${ }^{5051}$ that found a greater number of gastric ulcers in NSAID patients infected with $H$ pylori compared with patients either taking NSAIDs or infected with $H$ pylori. The prevalence of NSAID related ulcers in $H$ pylori positive patients has also been found to be twice that in $H$ pylori negative subjects, but the differences were not significant due to the small numbers of patients and ulcers studied..$^{52} 53$ Graham et $a l^{52}$ found a greater number of submucosal haemorrhages and erosions in $H$ pylori negative NSAID users, unlike the results of another report, which suggested that the presence of $H$ pylori had no influence on the prevalence of such lesions after the acute administration of naproxen or aspirin in healthy volunteers. ${ }^{54}$ Also, Shallcross et $a l^{53}$ found more duodenal than gastric ulcers in their NSAID patients, which is not typical of NSAID related damage, and could be explained by the fact that they included in their study patients who were able to stop their NSAID within a month before endoscopy. This would in turn raise concern about the suitability of such subjects for analysis and their need for and compliance with NSAID intake, which can determine the extent of peptic damage. A more recent study in asymptomatic NSAID users from the community has found that $H$ pylori infection was not related to the severity of the endoscopic findings, but to higher degrees of gastritis, ${ }^{55}$ which in the long term might progress to ulceration. ${ }^{56}$

The interpretation of the findings related to submucosal haemorrhages or erosions is made difficult by the chronic nature of $H$ pylori infection, its association with ulcers, and the lack of evidence that such minor lesions can really progress to ulcers. Another possible explanation for the differences in the findings of these studies ${ }^{4150-55}$ is the failure to correct for the presence of chemical gastritis, which appears to act as an independent factor, and the use of serological tests of unproved value in patients treated with NSAIDs. Diagnostic titres of $H$ pylori IgG antibodies could still be detected in patients with chemical gastritis, with its high prevalence of NSAID ulcers, despite the failure to confirm the presence of the organisms by culture, histology, or urease activity. ${ }^{5758}$ Also serology might not be reliable enough in predicting the presence of $H$ pylori or ulcers in NSAID patients, unlike other categories of patients, ${ }^{5960}$ because: firstly, NSAID ulcers can be completely without symptoms ${ }^{6162}$; secondly, the specificity of some IgG tests might be low in patients receiving NSAIDs ${ }^{575}$; thirdly, despite the apparent synergistic relation between $H$ pylori and NSAIDs, the intake of such drugs might be associated with a reduced prevalence of $H$ pylori infection ${ }^{41}$ 57 63-65: this could be due to a direct toxic action, or indirectly related to the increase in acid secretion ${ }^{1-4}$ and the interference with the mucus layer ${ }^{21-27}$ rendering the natural habitat of $H$ pylori organisms unsuitable for their survival.

The virulence of $H$ pylori strains might also explain some of the differences in the reported rates of ulcer formation. Western blotting analysis of systemic IgG or IgA responses to $H$ pylori has shown the antigenicity of $110-120 \mathrm{kDa}, 89 \mathrm{kDa}$, $61 \mathrm{kDa}, 54 \mathrm{kDa}$, and $31 \mathrm{kDa}$ proteins, although there is substantial variability among subjects. ${ }^{66-70}$ The $120 \mathrm{kDa}$ protein, which is recognised systemically in $83 \%$ of $H$ pylori positive subjects, is a surface protein not expressed in some $H$ pylori strains. ${ }^{68}$

It has been suggested that $120 \mathrm{kDa}$ positive strains have pathogenetic features associated with active gastritis and peptic ulcerations. ${ }^{70}$ Infection with $120 \mathrm{kDa}$ negative strains might explain why peptic ulceration develops in only a proportion of subjects infected with $H$ pylori..$^{70}$ A vaculating cytopathic agent has also been described in some strains of $H$ pylori. ${ }^{11}$ It is not, however, known whether these important findings would apply to patients receiving long term NSAIDs.

\section{Therapeutic considerations}

The role of eradicating $H$ pylori in the healing or the prevention of NSAID related peptic ulcers has not been studied. As well as their antibacterial activity, however, agents currently used in the treatment of $H$ pylori infection were previously found to possess properties relevant to the mechansims of NSAID induced mucosal damage. Colloidal bismuth subcitrate was shown to stimulate gastric and duodenal alkaline secretion through a prostaglandin dependent mechanism. ${ }^{72}$ The same agent was also found to have a protective action against aspirin induced microbleeding, and this protection occurred despite a pronounced suppression of mucosal prostaglandin production..$^{73}$ Also, it was shown that the ulcerogenic effect of NSAIDs could be reduced in animals by treatment with antibiotics, ${ }^{74}$ and that germ free animals were resistant to indomethacin induced intestinal lesion. ${ }^{75} 76$ 
The common nature of NSAID related ulcers in association with $H$ pylori colonisation, especially in elderly patients, should act as an incentive to devise an effective therapeutic approach. In 1983, enough NSAIDs were made available to treat almost three million people daily in the United States, ${ }^{77}$ and 22 million prescriptions were issued for such agents in the United Kingdom. ${ }^{7}$

About half of the NSAIDs prescribed were for persons over 60 years old ${ }^{78} \mathrm{H}$ pylori infection can be identified in about $80 \%$ of people of this age group ${ }^{79}$ although in the presence of NSAIDs the prevalence of $H$ pylori might fall to $30 \%$ to $50 \%$, according to data collected at our unit between 1987 and 1992.

It is estimated, therefore, that between $25 \%$ and $40 \%$ of all NSAID users and $30-50 \%$ of elderly patients taking NSAIDs could be infected with $H$ pylori and, as a result, are at special risk of developing peptic ulcers. The management of ulcers in this large number of patients is not only essential but might also need to be different from that of other types of ulcers. Its effect on ulcer complications, especially in elderly patients, also needs to be clarified.

Despite the evidence for a low prevalence of $H$ pylori in chronic NSAID users, it has to be emphasised that the possible use of NSAIDs to eradicate $H$ pylori should not be considered, knowing that such eradication might involve the impairment of the mucus layer with its damaging consequences.

In conclusion, the evidence for a synergistic relation between NSAIDs and $H$ pylori, despite being contested, should not be ignored because of its potential therapeutic implications. Also, the suggestion that NSAIDs might influence the prevalence of $H$ pylori would indicate that the two factors are uncomfortable partners in peptic ulcer disease.

A S TAHA

Gastroenterology Unit,

Royal Infirmary,

1 Feldman M. Colturic TJ. Effect of indomethacin on gastric acid and bicarbonate secretion in humans. Gastroenterology 1984; 87: 1339-43,

2 Gerkens JR, Shand DG, Flexner C, Nies A, Oates J, Data J. Effect of indomethacin and aspirin on gastric blood flow and acid secretion. $\mathcal{F}$ Pharmacol Exp Ther 1977; 203: 646-52.

3 Levine RA, Schwartzel EH. Effect of indomethacin on basal and histamine stimulated human gastric acid secretion. Gut 1984; 25: 718-22.

4 Levine RA, Jyotirmoy N, King RL. Non-salicylate non-steroidal antiinflammatory drugs augment prestimulated acid secretion in rabbit parietal cells. Investigations of the mechanisms of action. Gastroenterology 1991; 101 : 756-65.

5 Smith JTL, Pounder RE, Nwokolo CU, Lanzon-Miller S, Evans DG, Graham DY, Evans (Jr) DJ. Inappropriate hypergastrinaemia in asymptomatic healthy subjects infected with Helicobacter pylori. Gut 1990; 31:522-25.

6 Wagner S, Gladiziwa U, Haruma K, Verrentrapp M, Gebel M. Effect of Helicobacter pylori infection on 24 hour intragastric acidity in patients with gastritis and duodenal ulcer. Gut 1992; 33: 1024-8.

7 Marshall BJ, Armstrong JA, McGechie DB, Glancy RJ. Attempt to fulfil Koch's postulates for pyloric Campylobacter. Med F Aust 1985; 142: 436-7.

8 Morris A, Nicholson G. Ingestion of Campylobacter pyloridis causes gastritis and raised fasting gastric pH. Am $\mathcal{F}$ Gastroenterol 1987; 82: 192-9.

9 Peterson W, Lee E, Skoghund M. The role of Campylobacter pyloridis in epidemic gastritis with hypochlorhydria. Gastroenterology 1987; 92: A1575.

10 Graham DY, Smith JL, Alpert LC, Yoshimura HH. Epidemic achlorhydria is not viral but is caused by Campylobacter pyloridis. Gastroenterology 1987; 92: A1412.

11 Cave DR, Vargas M. Effect of Campylobacter pylori protein on acid secretion by parietal cells. Lancet 1989; ii: 187-9.

12 Chittajallu RS, Harwood J. Dorrian CA, McColl KEL. Is Helicobacter pylori related hypergastrinaemia due to the bacterium inhibiting parietal cel function. Gut 1991; 32: A1206.

13 Graham DY, Lew GM, Lechago J. Helicobacter pylori related increase in plasma gastrin: What is the status of the antral $\mathrm{G}$ cells in man? Gastroenterology 1991; 100: A75.

14 Chittajallu RS, Dorrian CA, Neithercut WD, Dahill S, McColl KEL. Is Helicobacter pylori associated hypergastrinaemia due to the bacterium's urease activity or the antral gastritis? Gut 1991; 32: 1286-90.

15 Wyatt JI, Rathbone BJ, Green DM, Primrose J. Raised fasting serum gastrin in chronic gastritis is independent of Campylobacter pylori status and duodenal chronic gastritis is independent of
ulceration. Gut 1989; 30: A1483.

16 Teichmann RK, Pratscheke E, Grab J, Hammer C, Brendel W. Gastrin release by interleukin-2 and gamma-interferon in vitro. Can $\mathcal{F}$ Physiol Pharmacol 1986; 64 (suppl): 62

17 Taha AS, Fraser WD, Kelly RW, Gemmell CG, Lee FD, Russell RI Inhibition of human gastric cyclic AMP production by Helicobacter pylor protein - possible involvement of mucosal prostaglandin $\mathrm{E}_{2}$. Aliment Pharmacol Therap 1991; 5: 379-89.
18 De Witte RJ, Geerdink PJ, Lamers CB, Boerbooms AM, Van der Korst JK. Hypochlorhydria and hypergastrinaemia in rheumatoid arthritis. Ann Rheum Dis 1979; 38: 14-7.

19 Ehsannullah RSB, Page MC, Tildesley G, Wood JR. Prevention of gastroduodenal damage induced by non-steroidal anti-inflammatory drugs: controlled trial of ranitidine $B M \mathcal{F} 1988 ; 297$ : 1017-21.

20 Lanza FL, Aspinal RL, Swabb EA, Davies RE, Rack MF, Rubin A. Doubleblind, placebo-controlled endoscopic comparison of the mucosal protective effects of misoprostol versus cimetidine on tolmetin-induced mucosal injury to the stomach and duodenum. Gastroenterology 1988; 95: 284-94.

21 Menguy R, Masters YF. Effect of aspirin on gastric mucus secretion. Surg Gynaecol Obstet 1965; 120: 92-8.

22 Menguy R, Desbaillets L. Role of inhibition of gastric mucous secretion in the phenomenon of gastric mucosal injury by indomethacin. American fournal of Digestive diseases 1967; 12: 862-6.

23 Sarosiek J, Mizuta K, Slomiany A, Slomiany B. Effect of acetylsalicylic acid on gastric mucin activity, permeability to hydrogen ion, and susceptibility to pepsin. Biochem Pharmacol 1986; 35: 4291-5.

24 Rees WDW, Bribbons LC, Turnberg LA. Effect of non-steroidal antiinflammatory drugs and prostaglandins on alkaline secretion by rabbit gastric inflammatory drugs and prostaglandins

25 Baskin W, Ivey KJ, Kraus WJ, Jeffrey G, Gemmell RT. Aspirin induced ultrastructural changes in human gastric mucosa: correlation with potential ultrastructural changes in human gastric mucosa:

26 Rainsford KD, Willis C. Relationship of gastric mucosal damage induced in pigs by anti-inflammatory drugs to their effect on prostaglandin production. Dig Dis Sci 1976; 21: 155-64.

27 Cooke AR. The role of the mucosal barrier in drugs induced gastric ulceration and erosions. Dig Dis Sci 1976; 21 : 155-64.

28 Sarosiek J, Slomiany A, Slomiany BL. Evidence for weakening of gastric mucus integrity by Campylobacter pylori. Scand f Gastroenterol 1988; 23 : 585-90.

29 Taha AS, McLaughlin S, Holland PJ, Kelly RW, Sturrock RD, Russell RI Effect on gastric and duodenal mucosal prostaglandins of repeated intake of therapeutic doses of naproxen and etodolac in rheumatoid arthritis. Ann Rheum Dis 1990; 49: 354-8.

30 Redfern JS, Lee E, Feldman M. Effects of indomethacin on gastric mucosa prostaglandins in humans. Correlation with mucosal damage. Gastroprostaglandins in humans.

31 Morley J, Bray MA, Jones RW, Nugteren DM, Van Drop DA. Prostaglandin and thromboxane production by human and guinea pig macrophages and leucocytes. Prostaglandins 1979; 17: 730-6.

32 Hawkey CJ. Synthesis of prostaglandin $E_{2}$, thromboxane $B_{2}$, and prostaglandin catabolism in gastritis and gastric ulcer. Gut 1986; 27: 1484-92.

33 Taha AS, Boothman P, Holland P, McKinlay A, Upadhyay R, Kelly RW, Lee F, Russell RI. Gastric mucosal prostaglandin synthesis in the presence of Campylobacter pylori in patients with gastric ulcer and non-ulcer dyspepsia. Am $\mathcal{F}$ Gastroenterol 1990; 85: 47-50.

34 Cryer B, Faust TW, Goldschmiedt M, Redfern JS, Lee E, Feldman M. Gastric and duodenal mucosal prostaglandin concentrations in gastric or duodenal ulcer disease: relationships with demographic, environmental and histoulcer disease: relationships with demographic, enviral
logical factors. Am $\mathcal{F}$ Gastroenterol 1992; 87: 1747-55.

35 Sievert W, Lambert JR, Peacock T, Nicholson L. Gastroduodenal mucosa prostaglandin synthesis: is there an association with Helicobacter pylori and chronic active gastritis? Gastronenterology 1991; 100: A161

36 Goren A, Fotherby KJ, Shorthouse M, Wight DGD, Hunter JO. Campylobacter pylori and acid secretion. Lancet $1989 \mathrm{ii}: 212-3$

37 Taha AS, Kelly RW, Gemmell CG, Lee FD, Russell RI. The interaction between Helicobacter pylori culture filtrate and indomethacin: effects on the integrity of human gastric antral mucosa and its prostaglandin $\mathrm{E}_{2}$ production in vitro. Aliment Pharmacol Therap 1990; 4: 265-74.

38 Gana TJ, MacPherson BR, Koo J. Gastric mucosal blood flow in misoprosto pretreated aspirin-induced ulceration. Ann Surg 1988; 207: 327-34.

39 Arakawa T, Nakamura H, Chono S, Satoh H, Fukuda T, Saeki Y, Kobayash $K$. Absence of effect of 16,16 -dimethyl prostaglandin $E_{2}$ on reduction of gastric mucosal blood flow caused by indomethacin in rats. Dig Dis Sci 1989 34: 1369-73.

40 Taha AS, Angerson W, Nakshabendi J, Beekman H, Morran C, Sturrock RD, et al. Gastric and duodenal mucosal blood flow in patients receiving nonsteroidal anti-inflammatory drugs - influence of age, smoking, ulceration, and Helicobacter pylori. Aliment Pharmacol Therap 1993; 7: 41-5.

41 Taha AS, Nakshabendi I, Lee FD, Sturrock RD, Russell RI. Chemical gastritis and Helicobacter pylori related gastritis in patients receiving non-steroida anti-inflammatory drugs: comparison and correlation with peptic ulceration $\mathcal{F}$ Clin Pathol 1992; 45: 135-9.

42 Rosam AC, Wallace JL, Whittle BJR. Potent ulcerogenic actions of plateletactivating factor on the stomach. Nature 1986; 319: 54-6.

43 Denizot Y, Shobhaui J, Rambaud JC, Lewin M, Thomas Y, Benveniste J. PAF-acether synthesis by H pylori. Gut 1990; 38: 1242-6.

44 Wallace JL, Keenan CM, Granger N. Gastric ulceration induced by nonsteroidal anti-inflammatory drugs is a neutrophil-dependent process. $A m \mathcal{F}$ Physiol 1990; 259: G462-7.

45 Trevethick MA, Clayton NM, Strong P, Harman IW. Do infiltrating neutrophils contribute to the pathogenesis of indomethacin induced ulceration of the rat gastric antrum? Gut 1993; 34: 156-60.

46 Sobala GM, King RFG, Axon ATR, Dixon MF. Reflux gastritis in the intact stomach. F Clin Pathol 1990; 43: 303-6.

47 Dixon MF, O'Connor HJ, Axon ATR, King RFJG, Johnston D. Reflux gastritis: distinct histopathological entity? F Clin Pathol 1986; 39: 524-30.

48 Laine L, Marin-Sorensen M, Weinstein WM. The histology of gastric erosions in patients taking non-steroidal anti-inflammatory drugs (NSAIDs): prospective study. Gastroenterology 1988; 94: A247.

49 Graham DY, Smith JL, Spjut HJ, Torres E. Gastric adaptation: studies in humans during continuous aspirin administration. Gastroenterology 1988; 95 : 327-33.

50 Martin DF, Montgomery E, Dobek AS, Patrissi GA, Peura DA. Campylobacter pylori, NSAIDs, and smoking: risk factors for peptic ulcer disease. Am $\mathcal{F}$
Gastroenterol 1989; 84: 1268-72.

51 Hudson N, Taha AS, Sturrock RD, Russell RI, Hawkey CJ. The influence of Helicobacter pylori colonisation on gastroduodenal ulceration in patients on non-steroidal anti-inflammatory drugs Gut 1992; 33: (suppl 1) S42.

52 Graham DY, Lidsky MD, Cox AM, et al. Long-term non-steroidal antiinflammatory drug use and Helicobacter pylori infection. Gastroenterology 100: 1653-7.

53 Shallcross TM, Rathbone BJ, Wyatt JI, Heatley RV. Helicobacter pylori 
associated chronic gastritis and peptic ulcerations in patients taking nonsteroidal anti-inflammatory drugs. Aliment Pharmacol Therap 1990; 4: 51522.

54 Lanza FL, Evans DG, Graham DY. Effect of Helicobacter pylori infection on the severity of gastroduodenal mucosa injury after the acute administration of the severity of gastroduodenal mucosa injury after the acute administration of napro

55 Loeb DS, Talley NJ, Ahlquist DA, Carpenter HA, Zinsmeister AR. Longterm non-steroidal anti-inflammatory drug use and gastroduodenal injury: the role of Helicobacter pylori. Gastroenterology 1992; 102: 1899-905.

56 Dixon MF, Sobala GM. Gastritis and duodenitis: the histopathological spectrum'Eur f Gastroenterol Hepatol 1992; 4: (suppl 2) S17-23.

57 Taha AS, Boothman P, Nakshabendi I, Reid J, Morran C, Gemmell CG, et al. Diagnostic tests for Helicobacter pylori - comparison and influence of nonsteroidal anti-inflammatory drugs. $\mathcal{F}$ Clin Pathol 1992; 45: 135-9.

58 Taha AS, Reid J, Boothman P, Gemmell CG, Lee FD, Sturrock RD, et al. Serological diagnosis of Helicobacter pylori - evaluation of four tests in the presence or absence of non-steroidal anti-inflammatory drugs. Gut 1993; 34: presence 0

59 Sobala GM, Crabtree JE, Pentith JA, Rathbone JA, Shallcross TM, Wyatt JI, et al. Screening dyspepsia by serology to Helicobacter pylori. Lancet 1991; ii: $94-6$.

60 Graham DY. Helicobacter pylori and the endoscopist: Whether to diagnose Gastrointest Endosc 1991; 37: 577-9.

61 Skander MP, Ryan FP. Non-steroidal anti-inflammatory drugs and pain-free peptic ulceration in the elderly. $B M \mathcal{F} 1988 ; 297: 833-4$.

62 Taha AS, Capell HA, Sturrock RD, Russell RI. Non-steroidal peptic damage in rheumatoid patients receiving second-line drugs. Am $\mathcal{F}$ Gastroenterol 1991; 86: 1588-91.

63 Caselli M, Pazzi P, La Corte R, Aleotti A, Trevisani L, Stabellini G. Campylobacter-like organisms, non-steroidal anti-inflammatory drugs and gastric lesions in patients with rheumatoid arthritis. Digestion 1989; 44: 101gast

64 Laine L, Marin-Sorensen M, Weinstein WM. Helicobacter pylori (HP) prevalence and mucosal injury in gastric ulcers (GUs): relationship to chronic non-steroidal anti-inflammatory drug (NSAID) ingestion. Gastroenterology 1991; 100: A103.

65 Marshall BJ, McGeckie DB, Rogers PA, Glancy RJ. Pyloric campylobacter infections and gastroduodenal disease. Med $\mathcal{F}$ Aust 1985; 142: 439-44.

66 Von Wulffen H, Grote HJ, Gatermann S, Loning T, Berger B, Buhl C.
Immunoblot analysis of immune response to Campylobacter pylori and its clinical associates. F Clin Pathol 1988; 41: 653-9.

67 Newell DG. Identification of the outer membrane proteins of Campylobacter pyloridis and antigenic cross reactivity between $C$ pyloridis and $C$ fejuni. $\mathcal{F}$ Clin Microbiol 1987; 133: 163-70.

68 Apel I, Jacobs E, Kist M, Bredt W. Antibody response of patients against a 120 $\mathrm{kDa}$ surface protein of Campylobacter pylori. Zentralbl Bacteriol Microbiol Hyg [A] 1988; 268: 271-6.

69 Crabtree JE, Mahony MJ, Taylor JD, Heatley RV, Littlewood JM, Tompkins DS. Immune responses to Helicobacter pylori in children with recurrent abdominal pain. $\mathcal{f}$ Clin Pathol 1991; 44: 768-71.

70 Crabtree J E, Taylor JD, Wyatt JI, Heatley RV, Shallcross TM, Tompkins DS, Rathbone BJ. Mucosal IgA recognition of Helicobacter pylori $120 \mathrm{kDa}$ protein, peptic ulcerations and gastric pathology. Lancet 1991; ii: 332-5.

71 Figura N. Guglielmetti P, Rossolini A, Barberi A, Cusi G, Musmanno RA, Russi M, Quaranta S. Cytotoxin production by Campylobacter pylori strains isolated from patients with peptic ulcers and from patients with chronic isolated from patients with peptic ulcers and
gastritis only. $\mathcal{f}$ Clin Microbiol $1989 ; 27: 225-6$.

72 Konturek SJ, Bilski J, Kwiecien N, et al. De-Nol Stimulates gastric and duodenal alakaline secretion through prostaglandin-dependent mechanism. Gut 1987; 28: 1557-63.

73 Konturek SJ, Kwiecien N, Obtulowicz W, et al. Effect of colloidal bismuth subcitrate on aspirin-induced gastric microbleeding, DNA loss, and prostaglandin formation in humans. Scand f Gastroenterol 1988; 23: 861-6.

74 Kent TH, Cardelli RM, Stanler FW. Small intestinal ulcers and intestinal flora in rats given indomethacin. Am F Pathol 1969; 54: 237-49.

75 Robert A, Asano T. Resistance of germ-free rats to indomethacin-induced intestinal lesions. Prostaglandins 1977; 14: 333-41.

76 Bjarnason I, Hayllar J, Smethurst P, Price A, Gumpel MJ. Metronidazole reduces intestinal inflammation and blood loss in non-steroidal antiinflammatory drug induced enteropathy. Gut 1992; 33: 1204-8.

77 Baum C, Kennedy DL, Forbes MB. Utilization of non-steroidal antiin $\mathrm{C}$, Kennedy DL, Forbes MB.

78 Walt R, Katchinski B, Logan R, Ashley L, Langman MJS. Rising frequency of ulcer perforations in elderly people in the United Kingdom. Lancet 1986; i:

79 Graham DY, Klein PD, Opekun AR, Boutton TW. Effect of age on the frequency of active Campylobacter pylori infection diagnosed by the [13C urea breath test in normal subjects and patients with peptic ulcer disease. $\mathcal{F}$ 